\title{
PENERAPAN SUSTAINABLE SILENT READING DALAM MENINGKATKAN BUDAYA BACA
}

\author{
Suharlik \\ SMP Negeri 5 Batu, Jalan Lapangan Lemahputih Sumberbrantas Batu \\ Email: like_har@yahoo.com
}

\begin{abstract}
The purpose of this research is to know the application of sustainable silent reading (SSR) in improving reading culture in Public Yunior High School 5 Batu (SMP Negeri 5 Batu). The research method used is School Action Research (PTS) with two cycles. The subjects of the study were students and educators of SMP Negeri 5 Batu as many as 98 people. Data were taken by interview, observation, and test. Data were analyzed descriptively. The results showed that the application of sustainable silent reading can improve reading culture in SMP Negeri 5 Batu. In Cycle I with an average value of 62.86 and the average value of the average value of Cycle II 80.39 so from the observation of two cycles there is an increase in journal value of $27.89 \%$. Increase in reading culture can be influenced by internal factors such as interest for reading and external factors, namely motivation and facilities and infrastructure.
\end{abstract}

Keywords: reading culture, sustainable silent reading

\begin{abstract}
Abstrak: Tujuan dari penelitian ini adalah untuk mengetahui penerapan sustainable silent reading (SSR) dalam meningkatkan budaya baca di SMP Negeri 5 Batu. Metode penelitian yang digunakan ialah Penelitian Tindakan Sekolah (PTS) dengan dua siklus. Subyek penelitian ialah peserta didik dan tenaga pendidik SMP Negeri 5 Batu sebanyak 98 orang. Data diambil dengan dengan wawancara, observasi, dan tes. Data dianalisis secara diskriptif. Hasil penelitian menunjukkan bahwa penerapan sustainable silent reading dapat meningkatkan budaya baca di SMP Negeri 5 Batu. Pada Siklus I dengan nilai rata-rata 62,86 dan nilai jurnal rata-rata nilai Siklus II 80,39 jadi dari pengamatan dua siklus terdapat kenaikan nilai jurnal sebesar 27,89\%. Kenaikan budaya membaca dapat dipengaruhi faktor internal yaitu minat seoarang untuk membaca dan faktor eksternal yaitu motivasi dan sarana dan prasarana.
\end{abstract}

Kata kunci: budaya baca, sustainable silent reading

Pentingnya budaya membaca bagi peserta didik untuk menambah pengetahuan, dengan menambah pengetahuan akan menumbuhkan kecerdasan peserta didik. Kecerdasan dan pengetahuan dihasikan beberapa ilmu pengetahuan yang didapat dari informasi yang diperoleh dari lisan maupun tulisan. Semakin banyak pengetahuannya maka semakin tinggi peradabannya. Informasi diperoleh salah satunya dengan jalan membaca. Membaca merupakan suatu cara untuk mendapatkan informasi dari sesuatu yang ditulis, dengan membaca semua informasi dapat ditangkap, dicerna dengan mudah dan cepat. Mengapa budaya membaca sangat penting, karena budaya membaca memiliki pesan yang sangat penting dalam kontek dalam umat manusia, terlebih saat ini dalam perkembangan ilmu pengetahuan dan teknologi informasi disampaikan dalam bentuk tulisan. Membaca merupakan satu alat komunikasi yang amat diperlukan dalam suatu masyarakat berbudaya.

Munaf (2002) menyatakan dengan membaca dapat diketahui sejarah suatu bangsa, kejadiankejadian atau peristiwa-peristiwa waktu lampau, maupun waktu sekarang di tempat lain, atau berbagai cerita yang menarik tentang masalah kehidupan di dunia ini. Budaya membaca sangat bermanfaat untuk memperdalam ilmu pengetahuan baik itu dari sekolah maupun dari luar sekolah, karena kita hanya dapat beberapa dari sekolah dan sisanya pengetahuan kita peroleh sendiri. Dengan budayakan membaca sejak dini akan membuat kita tahu akan dunia diluar rumah kita tanpa harus 
keluar dari rumah. Membaca dipandang sebagai suatu kegiatan yang amat strategi dan mendasar dalam perkembangan kepribadian/psikologi pada setiap diri manusia. Kenyataan ini dapat dilihat dari kebiasaan seseorang, bahwa apa yang dibaca akan berpengaruh terhadap pola pikir dan perilakunya pada kehidupan sehari-hari. Arisma (2012) menyatakan penerapan program jam baca mampu meningkatkan minat dan kemampuan membaca siswa.

Penerapan jam baca yang rutin dilaksanakan di sekolah-sekolah akan memberikan dampak positif bagi peningkatan perilaku membaca anak bangsa di masa yang akan datang. Program wajib baca di SMP Negeri 5 Batu mulai diterapkan oleh manajemen sekolah sejak tahun ajaran 2014 hingga sekarang. Program wajib baca ini dijadwalkan dalam seminggu dilaksanakan tiga hari mulai hari selasa, rabu, dan kamis, setiap hari selama 15 menit sebelum pembelajaran jam pertama. Program wajib baca sejak semester genap di tahun pelajaran 2016 diterapkan wajib baca untuk Kelas VII dan Kelas VIII waktu 40 menit. Namun kenyataan tidak banyak perbedaan dengan uraian diatas bahwa minat baca peserta didik di SMP Negeri 5 Batu, minat baca rendah dan kurang maksimal terlaksana. Sejak dilaksanakan program wajib baca bertujuan membiasakan peserta didik dapat menambah pengetahuan dan memperoleh ilmu secara mandiri dari buku yang mereka baca. Dengan membaca akan didapatkan informasi yang lebih jelas dan komplek.

Membaca merupakan kegiatan yang hal ini sesuai dengan pendapat Nurhadi (1987) yang menyatakan bahwa membaca adalah sebuah proses yang kompleks dan rumit. Kompleks artinya dalam proses membaca terlibat faktor internal dan faktor eksternal pembaca. Faktor internal dapat berupa intelegensi (IQ), minat, sikap, bakat, motivasi, tujuan membaca. Faktor eksternal bisa dalam membentuk sarana membaca, teks bacaan, faktor lingkungan, atau faktor latar belakang sosial ekonomi, kebiasaan, dan tradisi membaca. Menurut Tampubolon (1987) membaca merupakan salah satu kemampuan yang harus dibina dan dikembangkan. Selain kompleksitas membaca, guru juga perlu memperhatikan rendahnya minat baca peserta didik yang kini menjadi masalah besar di Indonesia.
Kurang maksimalnya tingkat budaya membaca di SMP Negeri 5 Batu disebabkan beberapa faktor, diantaranya faktor internal minat, sikap dan motivasi, Faktor eksternal lingkungan, sarana membaca perpustakaan. Faktor yang merupakan salah satu penyebab kurangnya minat baca peserta didik diantaranya kurangnya kesadaran masing-masing individu, terbukti dari data hasil studi pendahuluan yang dilakukan pengamatan kesiapan peserta didik melakukan wajib baca dihari petama $45 \%$ yang melaksanakan, dihari kedua ada $56 \%$. Kurang tertanam akan pentingnya membaca atau belum muncul dalam diri individu bahwa membaca akan menjadi kebutuhan bagi diri kita. Faktor motivasi dari berbagai pihak amat dibutuhkan terutama dari pendidik. Kenyataan selama ini peserta didik waktu program wajib baca mereka belum didampingi guru. Hal ini bisa dilihat hasil pemantauan selama ini guru mata pelajaran jam pertama rata-rata masuk lebih dari jam tujuh sebanyak $58 \%$.

Faktor penunjang lain yang sangat berperan adalah perpustakaan, kondisi saat ini perpustakaan kurang memadai karena bangunan mengalami kerusakan, sehingga suasana perpustakaan kurang nyaman. Masalah kemampuan membaca peserta didik yang kurang, akan dikaji oleh peneliti dengan beberapa cara untuk mencari solusi dalam meningkatkan budaya membaca peserta didik, diantaranya dengan penerapan metode sustained silent reading (SSR). SSR adalah kegiatan membaca dalam hati yang dilakukan oleh peserta didik. Kegiatan ini peserta didik diberi kesempatan untuk memilih sendiri buku yang akan dibacanya, sehingga mereka dapat menyelesaikan membaca bacaan sesuai dengan keinginannya. Pendidik dapat memberi contoh sikap membaca dalam hati yang baik sehingga mereka dapat meningkatkan kemampuan membaca dalam hati untuk waktu yang cukup lama.

\section{METODE}

Rancanganpenelitianinidenganmenggunakan rancangan Penelitian Tindakan Sekolah (PTS). PTS yang dilakukan oleh peneliti dengan 2 siklus. Masing-masing siklus terdiri dari 4 tahap, yaitu: tahap perencanaan, pelaksanaan, observasi, dan refleksi. Rancangan penelitian seperti Gambar 1. Pada tahap perencanaan ada empat langkah, 
yaitu: (1) menyusun rencanaan pelaksanaan; (2) sosialisasi kepada peserta didik dan pendidik; (3) menentukan observer; dan (4) menyusun instrumen. Pada tahap pelaksanaan dilakukan budaya baca oleh peserta didik dengan didampingi pendidik jam pertama sebagai kalaborator. Pada tahap observasi atau pengamatan dengan menggunakan lembar pengamatan. Langkah kegiatan dalam observasi adalah: (1) peserta didik menyiapkan buku bacaan yang sudah dibawa dari rumah atau meminjam dari perpustakaan; (2) melaksanakan SSR didampingi guru mata pelajaran jam pertama; (3) menuliskan resume dengan kalimatnya sendiri; (4) peserta didik menyampaikan secara lesan hasil resume keteman sebangkunya bergantian; dan (5) mengumpulkan hasil resume pada pendidik jam pertama. Dalam kegiatan observasi data dan informasi yang dikumpulkan adalah data tentang proses selama proses membaca dan data dari jurnal membaca. Peneliti sebagai observer mencatat semua peristiwa yang terjadi selama peserta didik membaca.

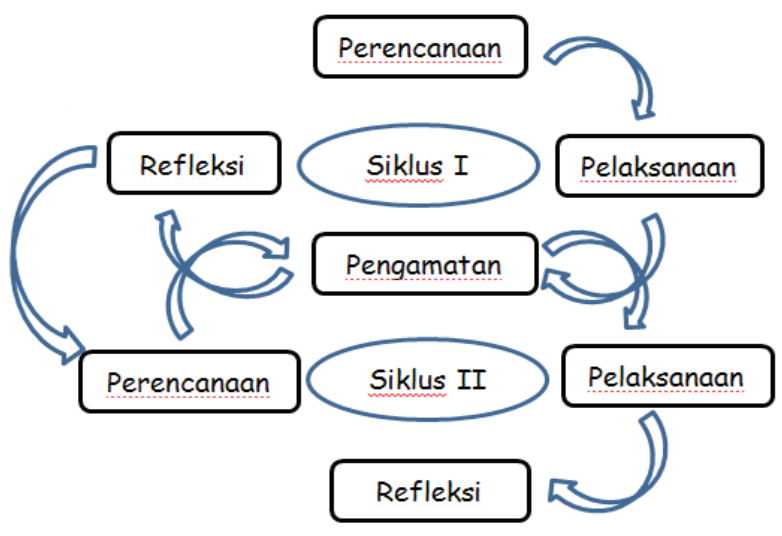

Gambar 1 Rancangan Penelitian Tindakan

Tahap refleksi pada dasarnya merupakan kegiatan analisis-sintesis, interpretasi, dan eksplanasi terhadap semua informasi yang diperoleh dari pelaksanaan tindakan. Setiap informasi yang didapat dikaji dan dipahami bersama peneliti dan observer. Informasi yang terkumpul perlu dicari kaitan antara satu tindakan dengan fakta yang ada dan dibandingkan dengan penelitian sebelumnya, juga dikaitkan dengan teori tertentu dengan hasil penelitian yang relevan. Subyek penelitian tindakan dilakukan pada peserta didik SMP Negeri 5 Batu kelas VII dan kelas VIII sejumlah 98 orang.

Instrumen penelitian yang digunakan untuk pelaksanaan penerapan SSR pada penelitian ini adalah: (1) lembar observasi; (2) wawancara; dan (3) jurnal membaca. Observasi dilakukan oleh peneliti untuk mengamati kegiatan program wajib baca berlangsung, pelaksanaan proses siklus yang diterapkan dan perilaku peserta didik berkaitan dengan pelaksanaan SSR. Dengan berpedoman pada lembar observasi, peneliti mengamati apa yang terjadi dalam proses pelaksanaan program wajib baca. Jurnal membaca digunakan untuk mengetahui kebarhasilan peserta didik terutama hasil resume membaca dalam memahami suatu konsep yang diperoleh atau dibaca dan dipakai sebagai indikator keberhasilan peserta didik dari hasil membaca. Wawancara dilakukan oleh peneliti digunakan untuk mengetahui minat membaca peserta didik sebelum program membaca. Wawancara dilakukan kepada pengelola perpustakaaan yang mengetahui minat membaca peserta didik secara langsung berdasarkan hasil presensi dan peminjaman buku di perpustakaan. Teknik tersebut dilakukan berdasarkan pada pedoman wawancara. Jurnal membaca digunakan untuk mengetahui hasil kemampuan kompetensi membaca peserta didik sebelum dan sesudah penerapan budaya membaca senyap, sehingga akan dapat diketahui adanya peningkatan yang terjadi atau tidak terjadi peningkatan.

Data yang diperoleh dari hasil teknik jurnal membaca berupa skor yang digunakan untuk menjawab rumusan masalah. Teknik ini berpedoman pada pedoman jurnal membaca dengan indikator yang dinilai meliputi: (1). kemampuan menulis identitas buku; (2) kemampuan peserta didik menulis ringkasan bahan bacaan; (3) kemampuan peserta didik memilih aspek dari bahan bacaan yang akan dikomentari; (4) kemampuan peserta didik menuliskan komentar serta alasan; dan (5) kemampuan peserta didik menuliskan kutipan pendukung dalam bahan bacaan sesuai yang dikomentari. Penetapan skor data kemampuan peserta didik menuliskan jurnal membaca menggunakan rumus:

$$
\mathrm{P}=\frac{\sum \text { skor }}{\mathrm{N}} \times 100
$$




\author{
Keterangan: \\ $\mathrm{P}=$ nilai kemampuan membuat \\ jurnal membaca \\ $\mathrm{N}=$ skor maksimal (Arikunto, 2006)
}

\section{HASIL}

\section{Siklus I}

Pada siklus satu tahapan pelaksanaan meliputi perencanan, pelaksanaan tindakan, pengamatan dan refleksi. Tahapan kegiatan tersebut diuraikan sebagai berikut:

\section{Perencanaan}

Tahappertamadalamperencanaan penyusunan siklus I adalah perencanaan, pelaksanaan, ada empat langkah, yaitu: (1) menyusun rencanaan pelaksanaan; (2) sosialisasi kepada peserta didik dan pendidik; (3) menentukan observer; dan (4) menyusun instrumen. Kegiatan penyusunan rencana pelaksanaan direncanakan dipilih kelas yang diamati kelas VII dan kelas VIII, untuk kelas IX tidak ikut menjadi subyek penelitian karena dalam semester ini kegiatan mulai jam ke nol bimbingan belajar jadi tidak mengikuti kegiatan budaya membaca. Langkah selanjutnya sosialisasi terhadap seluruh peserta didik, pendidik dan tenaga kependidikan serta pustakawan, sosialisasi dilakukan pada tanggal 20 Pebuari 2017 sebelum tindakan dimulai. Dalam sosialisasi diberitahukan bahwa kegiatan wajib baca akan dioptimalkan sesuai yang sudah di jadwalkan sebagai program wajib baca, yang dimulai setiap hari selasa sampai hari kamis sebelum pembelajaran jam pertama dimulai. Adapun waktu kegiatan wajib baca selama 40 menit.

Tahap ketiga menentukan observer dan membuat kesepakatan dengan observer, ditunjuk sebagai observer adalah penanggung jawab program wajib baca disekolah. Tahap keempat menyusun instrumen yang terdiri dari: (1) lembar observasi; (2) lembar wawancara; dan (3) jurnal membaca. Lembar observasi digunakan dalam menentukan indikator yang akan dilakukan peserta didik selama proses membaca, dengan rincian: (1) peserta didik menyiapkan buku bacaan yang sudah dibawa dari rumah atau meminjam dari perpustakaan; (2) melaksanakan SSR didampingi guru mata pelajaran jam pertama; (3) menuliskan resume dengan kalimatnya sendiri; (4) peserta didik menyampaikan secara lisan hasil resume yang dibaca keteman sebangkunya secara bergantian; dan (5) mengumpulkan hasil resume kepada guru jam pertama. Lembar wawancara digunakan untuk wawancara pustakawan, hal ini digunakan untuk mengetahui lebih awal sejauh mana minat baca peserta didik selama ini. Jurnal membaca dibuat untuk menentukan skor setiap peserta didik setelah melakukan kegiatan membaca dan juga digunakan sebagai indikator ketercapaian penerapan Sustainable Sailent Reading terhadap budaya baca.

\section{Pelaksanaan Tindakan}

Pelaksanaan tindakan dilaksanakan berdasarkan hasil perencanaan, diawali wawancara dengan tenaga perpustakaan sebagai berikut: (1) minat baca siswa di perpustakaan sekolah pada umumnya peserta didik; (2) frekuensi kedatangan peserta didik ke perpustakaan sekolah; (3) Peserta didik lebih sering meminjam buku; (4) buku yang sering dibaca; dan (5) sebelumnya ada kebijakan dari guru atau sekolah untuk meningkatkan minat membaca peserta didik dengan adanya program wajib baca 15 menit sebelum pembelajaran dimulai. Dalam pelaksanaan kegiatan membaca peneliti membuat catatan terhadap pendidik yang menemani selama peserta didik melakukan kegiatan membaca, sehingga akan diketahui peran serta pendidik dalam memotivasi terhadap kegiatan membaca peserta didik.

Pelaksanaan kegiatan budaya membaca dilakukan setiap hari selasa, rabu dan kamis, selama 40 menit sebelum jam pelajaran dimulai. Langkah kegiatan budaya membaca sebagai berikut: (1) Peserta didik menyiapkan buku bacaan yang sudah dibawa dari rumah atau meminjam dari perpustakaan salama 2 menit; (2) melaksanakan SSR didampingi guru mata pelajaran jam pertama selama 15 menit; (3) menuliskan resume dengan kalimatnya sendiri waktu 10 menit; (4) peserta didik menyampaikan secara lisan hasil resumenya keteman sebangkunya secara bergantian waktu 10 menit; dan (5) mengumpulkan hasil resume waktu 3 menit. Dalam pelaksanaan untuk mengetahui keberhasilan budaya membaca sebagai indikator setiap akhir siklus diberikan jurnal membaca. Jurnal membaca inilah yang akan menentukan skor 
ketercapaian peserta didik selama membaca. Jurnal membaca penilaian disesuaiakan dengan rubrik penilaian, komponen rubrik penilaian meliputi: (1) identitas buku yang dibaca; (2) resume / ringkasan yang ditulis menggunakan bahasa sendiri; dan (3) komentar dari isi bacaannya.

\section{Pengamatan}

Pengamatan dilakukan oleh peneliti dibantu oleh observer.Tindakan yang penulis gunakan adalah dengan menggunakan pengumpulan data atau informasi. Data informasi wawancara pelaksanaan tindakan dilaksanakan berdasarkan hasil perencanaan diawali wawancara dengan tenaga perpustakaan dengan hasil sebagai berikut: (1) minat baca siswa di perpustakaan sekolah pada umumnya peserta didik kurang berminat/ minat baca rendah; (2) frekuensi kedatangan peserta didik ke perpustakaan sekolah nunggu dipanggil atau datang ke perpustakaan hanya untuk meminjam buku waktu pelajaran karena tugas dari guru dan waktu wajib baca saja; (3) Peserta didik lebih sering meminjam buku untuk dibawa pulang; (4) buku yang sering dibaca buku fiksi, buku cerita, dan sedikit tentang pengetahuan umum; dan (5) sebelumnya ada kebijakan dari guru atau sekolah untuk meningkatkan minat membaca peserta didik dengan adanya program wajib baca 15 menit sebelum pembelajaran dimulai, akan tetapi masih ada banyak kekurangannya.

Selama pengamatan awal proses wajib baca selama siklus I kesiapan siswa melaksanakan wajib baca untuk kelas VII dari 57 peserta didik yang siap ada 41 jadi sekitar $71,92 \%$, yang melakukan, sedangkan kelas VIII dari 41peserta didik ada 27 peserta didik yang siap melaksanakan wajib baca jadi sekitar $65,85 \%$. Aktivitas peserta didik yang diamati pada siklus I adalah peserta didik menyiapkan buku bacaan yang sudah dibawa dari rumah atau meminjam dari perpustakaan belum seluruhnya siap, ada $15,3 \%$ yang tidak membawa dengan alas an lupa, dan belum pinjam dan buku sudah dikembalikan belum pinjam lagi. Pelaksanaan SSR didampingi guru mata pelajaran jam pertama belum semua kelas ada pendidik yang mendampingi karena kedatangan guru baru 42 persen tepat waktu. Peserta didik menuliskan resume dengan kalimatnya sendiri belum keselurahan dengan kata-kata sendiri, masih ada merangkum apa yang dibaca dari buku. Kegiatan peserta didik menyampaikan secara lisan hasil resumenya keteman sebangkunya terlaksana namun masih ada siswa yang tidak dengan teman sebanngku/yang dekat tapai pindah milih dengan teman yang mereka cocok. Pada tahap mengumpulkan hasil resume ini masih belum maksimal karena kendala guru jam pertama datang terlambat dan pendidik lupa tidak memberi paraf pada jurnal anak.

Keterlibatan pendidik dalam menemani peserta didik dalam budaya membaca selama siklus I kehadiran pendidik jam 7.00 - 7.15 saat jam wajib baca sebelum pelajaran pertama dimulai yang masuk tepat waktu ada $42 \%$, sedangkan kehadiran dikelas jam 7.20 -7.40 ada $58 \%$. Berdasarkan data maka kepedulian tenaga pendidik belum menunjukkan dukungan terhadap budaya membaca. Tingkat keberhasilan budaya membaca peserta didik selama siklus I ditunjukkan dengan penilaian jurnal membaca yang diberikan pada akhir siklus. Hasil data pengamatan sebagai berikut, dapat dilihat pada Gambar 2.

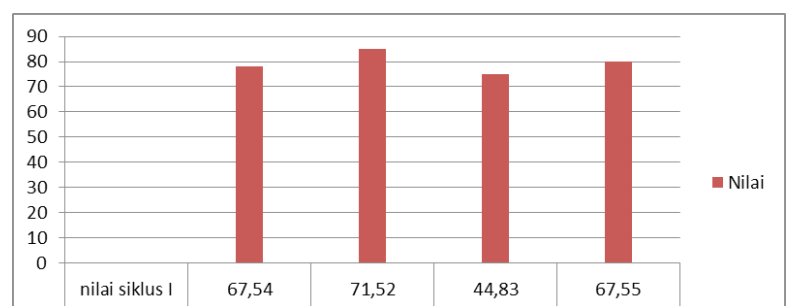

Gambar 2 Hasil Nilai Jurnal Membaca Siklus I

Berdasarkan Gambar 1 menunjukkan nilai penyusunan jurnal membaca peserta didik selama siklus satu adalah sebagai berikut, data pengamatan nilai rata-rata kelas $7 \mathrm{~A}$ nilai rata-rata 67,54 nilai rata-rata kelas 7B sebesar 71,52 untuk nilai kelas $8 \mathrm{~B}$ rata-rata 67,55 dan perolehan nilai kelas $8 \mathrm{~A}$ nilai rata-rata 44,83 . Hasil rata-rata budaya baca siklus I dari seluruh siswa 62,86 . Nilai rata-rata kelas 7B paling tinggi, berikutnya nilai rata-rata kelas $8 \mathrm{~B}$, urutan selanjutnya kelas $7 \mathrm{~A}$ dan paling rendah nilai rata- rata kelas $8 \mathrm{~A}$, urutan rata-rata nilai dikarenakan motivasi dari pendidik yang menemani program wajib baca oleh. Saat jam wajib baca semestinya ditemani guru jam pertama, namun kehadiran guru jam pertama datang pada saat jam pertama mulai. Selain motivasi pendidik juga minat baca peserta didik masih kurang. 


\section{Refleksi}

Dari catatan lapangan penerapan SSR terhadap budaya membaca masih ada beberapa faktor yang perlu ditingkatkan diantara faktor internal yaitu minat baca peserta didik dan kepedulian pendidik, selain itu faktor eksternal yaitu media berupa buku dan perpustakaan. Melihat masalah yang ditemukan pada siklus I untuk meningkatkan minat baca maka masih perlu diteruskan penulisan jurnal oleh peserta didik peserta didik dengan kata-kata sendiri. Langkah selanjutnya untuk meningkatkan kepedulian pendidik ikut memotivasi peserta didik, maka perlu diadakan pelatihan tentang pentingnya membaca. Untuk peningkatan faktor eksternal peningkatan pelayanan dan penyediaan buku. Jika dilihat dari data diatas dapat diketahui bahwa peserta didik yang melakukan budaya baca dengan rata-rata $89,79 \%$ dengan nilai rata-rata 62,86 maka perlu diadakan tindakan selanjutnya yaitu siklus II.

\section{Siklus II}

Pada siklus dua tahapan pelaksanaanya meliputi perencanan, pelaksanaan tindakan, pengamatan dan refleksi. Tahapan kegiatan tersebut diuraikan sebagai berikut:

\section{Perencanaan}

Tahap pertama dalam perencanaan penyusunan siklus dua adalah perencanaan, pelaksanaan, ada empat langkah, yaitu: (1) menyusun rencanaan pelaksanaan; (2) pelatihan kepada pendidik; (3) menentukan observer; dan (4) menyusun instrumen. Dalam sosialisasi diberitahukan bahwa kegiatan budaya baca tetap dilaksanakan sesuai yang sudah di jadwalkan sebagai program wajib baca, yang dimulai setiap hari selasa sampai hari kamis sebelum pembelajaran jam pertama dimulai. Adapun alokasi waktu kegiatan wajib baca selama 40 menit. Tahap ketiga menentukan observer dan membuat kesepakatan dengan observer, sebagai observer adalah penanggung jawab program wajib baca disekolah. Tahap keempat menyusun instrumen yang terdiri dari: (1) lembar observasi; (2) lembar wawancara; dan (3) jurnal membaca.

Lembar observasi digunakan dalam menentukan indikator yang akan dilakukan peserta didik selama proses membaca, dengan rincian sebagai berikut: (1) peserta didik menyiapkan buku bacaan yang sudah dibawa dari rumah atau meminjam dari perpustakaan; (2) melaksanakan SSR didampingi guru mata pelajaran jam pertama; (3) menuliskan resume dengan kalimatnya sendiri; (4) peserta didik menyampaikan secara lisan hasil resume yang dibaca keteman sebangkunya secara bergantian; dan (5) mengumpulkan hasil resume kepada guru jam pertama. Lembar wawancara digunakan untuk wawancara pustakawan dan peserta didik, wawancara digunakan untuk mengetahui sejauh mana minat baca peserta didik dan bagaimana respons selama kegiatan budaya baca dilaksanakan selama siklus satu. Jurnal membaca dibuat untuk menentukan skor setiap peserta didik setelah melakukan kegiatan membaca, dan juga digunakan sebagai indikator ketercapaian penerapan Sustainable Sailent Reading terhadap budaya baca.

\section{Pelaksanaan Tindakan}

Pelaksanaan tindakan dilaksanakan berdasarkan hasil siklus I, diawali wawancara dengan tenaga perpustakaan sebagai berikut: (1) minat baca peserta didik di perpustakaan sekolah pada umumnya; (2) frekuensi kedatangan peserta didik ke perpustakaan sekolah; (3) peserta didik lebih sering meminjam buku; (4) buku yang sering dibaca; dan (5) sebelumnya ada kebijakan dari guru atau sekolah untuk meningkatkan minat membaca peserta didik dengan adanya program wajib baca 40 menit sebelum pembelajaran dimulai. Dalam pelaksanaan kegiatan membaca peneliti membuat catatan terhadap pendidik yang menemani selama peserta didik melakukan kegiatan membaca, sehingga akan diketahui peran serta pendidik dalam memotivasi terhadap kegiatan membaca peserta didik.

Pelaksanaan kegiatan budaya membaca dilakukan setiap hari selasa, rabu dan kamis, selama 40 menit sebelum jam pelajaran dimulai. Langkah kegiatan budaya membaca sebagai berikut: (1) peserta didik menyiapkan buku bacaan yang sudah dibawa dari rumah atau meminjam dari perpustakaan salama 2 menit; (2) melaksanakan SSR didampingi guru mata pelajaran jam pertama selama 15 menit; (3) menuliskan resume dengan kalimatnya sendiri waktu 10 menit; (4) peserta didik menyampaikan secara lisan hasil resumenya 
keteman sebangkunya secara bergantian waktu 10 menit; dan (5) mengumpulkan hasil resume waktu 3 menit. Dalam pelaksanaan untuk mengetahui keberhasilan budaya membaca sebagai indikator setiap akhir siklus diberikan jurnal membaca. Jurnal membaca inilah yang akan menentukan skor ketercapaian peserta didik selama membaca. Jurnal membaca penilaian disesuaiakan dengan rubrik penilaian, komponen rubrik penilaian meliputi: (1) identitas buku yang dibaca; (2) resume / ringkasan yang ditulis menggunakan bahasa sendiri; dan (3) komentar dari isi bacaannya.

\section{Pengamatan}

Pengamatan dilakukan oleh peneliti dengan menggunakan pengumpulan data atau informasi. Data informasi wawancara pelaksanaan tindakan dilaksanakan berdasarkan hasil siklus I wawancara dengan tenaga perpustakaan dengan hasil sebagai berikut: (1) minat baca siswa di perpustakaan sekolah pada umumnya peserta didik cukup berminat; (2) frekuensi kedatangan peserta didik ke perpustakaan sekolah untuk meminjam buku waktu pelajaran karena tugas dari guru dan waktu wajib baca saja karena perpustakaan belum maksimal; (3) peserta didik lebih sering meminjam buku untuk dibawa pulang; (4) buku yang sering dibaca buku fiksi, buku cerita, dan sedikit tentang pengetahuan umum; dan (5) selama di optimalkan budaya baca untuk meningkatkan minat membaca peserta didik dengan adanya program wajib baca 40 menit sebelum pembelajaran dimulai, mulai meningkatkan.

Hasil wawancara dengan peserta didik $80 \%$ kurang setuju jika petugas perpustakaan yang menentukan buku yang akan dibaca, $82,5 \%$ setuju menentukan sendiri judul buku sesuai dengan keinginannya. $97,5 \%$ setuju waktu 40 menit untuk pembiasaan wajib baca. Peserta didik 95\% setuju jika guru pendamping di kelas saat wajib baca juga ikut membaca. Peserta didik 92,5\% setuju membuat ringkasan jurnal dengan bahasa sendiri. Selama pengamatan proses wajib baca selama siklus II kesiapan peserta didik melaksanakan wajib baca untuk kelas VII dari 57 peserta didik yang siap ada 48 jadi sekitar $84,21 \%$, yang melakukan, sedangkan kelas VIII dari 41peserta didik ada38 peserta didik yang siap melaksanakan wajib baca jadi sekitar $92,68 \%$.
Aktivitas peserta didik yang diamati pada siklus II adalah peserta didik menyiapkan buku bacaan yang sudah dibawa dari rumah atau meminjam dari perpustakaan belum seluruhnya siap, ada 05,3 \% yang tidak membawa dengan alasan ketinggalan. Pelaksanaan SSR belum semua kelas ada pendidik yang mendampingi. Peserta didik menuliskan resume dengan kalimatnya sendiri belum keselurahan dengan kata-kata sendiri, masih ada merangkum apa yang dibaca dari buku. Kegiatan peserta didik menyampaikan secara lisan hasil resumenya keteman sebangkunya terlaksana sudah sesuai dengan jadwal namun kurang maksimal. Pada tahap mengumpulkan hasil resume ini sudah maksimal sesuai yang dijadwalkan.

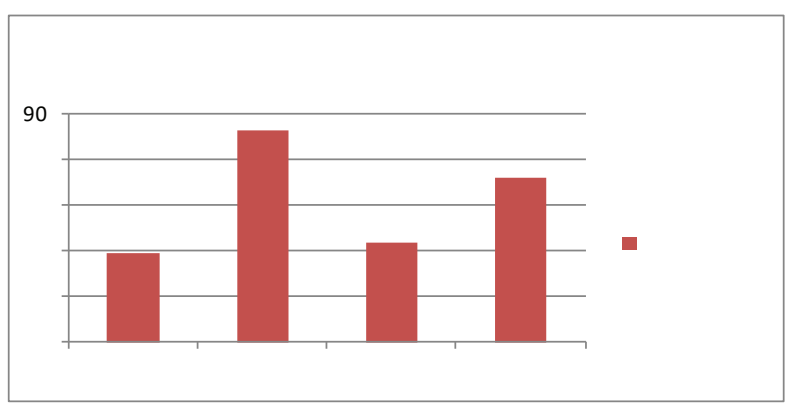

\section{Gambar 3 Hasil Penilaian Jurnal Membaca Siklus II}

Keterlibatan pendidik dalam menemani peserta didik dalam budaya membaca selama siklus II kehadiran pendidik jam 7.00 s.d. 7.15 saat jam wajib baca sebelum pelajaran pertama dimulai yang masuk tepat waktu ada $55 \%$, sredangkan kehadiran dikelas jam 7.20 s.d. 7.40 ada $45 \%$. Berdasarkan data maka kepedulian tenaga pendidik belum menunjukkan dukungan terhadap budaya membaca secara maksimal. Tingkat keberhasilan budaya membaca peserta didik selama siklus II ditunjukkan dengan penilaian jurnal membaca yang diberikan pada akhir siklus. Hasil data pengamatan sebagai berikut, dapat dilihat pada Gambar 3 .

Gambar 3 menunjukkan hasil nilai jurnal membaca peserta didik selama siklus dua, data pengamatan nilai rata-rata kelas $7 \mathrm{~B}$ memiliki hasil rata- rata 88,18 yang kedua kelas $8 \mathrm{~B}$ rata-rata 82,85 , urutan ketiga kelas $8 \mathrm{~A}$ nilai rata-rata 75,83 , kelas 7 A nilai rata-rata 74,69 . Hasil rata-rata nilai jurnal baca siklus II dari seluruh siswa 80,39. Jika dilihat dari hasil rata-rata kelas pada siklus 
II mengalami peningkatan, hal ini menunjukkan minat baca peserta didik mulai ada peningkatan. Selain minat peserta didik juga ada peningkatan motivasi pendidik menemani program wajib baca dikelas.

\section{Refleksi}

Dari catatan lapangan penerapan SSR terhadap budaya membaca beberapa faktor sudah ada peningkatan diantara faktor internal yaitu minat baca peserta didik dan kepedulian pendidik, selain itu faktor eksternal yaitu media berupa buku dan perpustakaan perlu adannya peningkatan. Jika dilihat dari data diatas pada siklus II dapat diketahui bahwa peserta didik yang melakukan budaya baca dengan rata-rata $94,89 \%$ dengan nilai rata-rata 80,39 , sedangkan siklus I rata-rata 62,86 sehingga ada kenaikan sebesar 27,89\%. Secara umum peserta didik setuju adanya program budaya baca, merangkum dengan kata-kata sendiri dan menceritakan pada temannya. Jadi dengan penerapan Sustainabel Sailent Reading dapat meningkatkan budaya membaca peserta didik di SMP 05 Batu. Selain penerapan SSR yang dapat meningkatkan budaya membaca adalah motivasi dari pendidik. Untuk mengetahui lebih lanjut maka perlu ada penelitian yang lain yang berkaitan dengan motivasi guru. Secara umum peningkatan rata-rata hasil penilaian dan tingkat keberhasilan dapat dilihat pada Tabel 1.

Tabel 1 Hasil Penilaian Jurnal Membaca Siklus I dan Siklus II

\begin{tabular}{cccc}
\hline Kelas & Siklus 1 & Siklus 2 & Selisih \\
\hline 7A & 67,54 & 74.69 & 7,15 \\
7B & 71,52 & 88.18 & 16,66 \\
8A & 44,83 & 75.83 & 31 \\
8B & 67,55 & 82.85 & 15,3 \\
\hline
\end{tabular}

Tabel 1 kenaikan nilai rata-rata siklus I dan siklus II pada kelas 7B terjadi kenaikan 16,66, kenaikan yang kedua pada kelas $8 \mathrm{~B}$ sebesar 15,3 urutan kenaikan berikutnya kelas $8 \mathrm{~A} 31,0$ dan kenaikan rata-rata urutan terakhir kelas 7A sebesar 7,15. Persentase kenaikan nilai jurnal membaca peserta didik dari siklus I dan siklus II dapat dilihat pada Gambar 4.

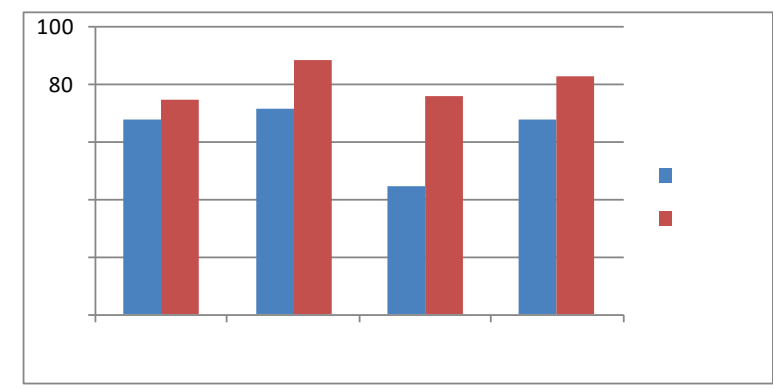

\section{Gambar 3 Hasil Penilaian Jurnal Membaca Siklus I dan Siklus II}

Berdasarkan gambar grafik diatas dapat dilihat tingkat keberhasilan budaya baca, dari kelas 7A siklus I 67,54 dan siklus II 74,69 sehingga ada kenaikan $10,59 \%$, kelas $7 \mathrm{~B}$ rata- rata nilai siklus I 71,52 dan siklus II 88,18 sehingga ada kenaikan sebesar 23,29\%, untuk kelas 8A nilai rata-rata siklus I 44,73 dan pada siklus II 75,73 jadi ada kenaikan sebesar $69,30 \%$, untuk kelas 8B nilai siklus I 76,55 nilai siklus II 82,85 jadi ada kenaikan sebesar $8,22 \%$. Dan secara keseluruhan pada siklus I ada peningkatan dari siklus I dan siklus II sebesar $27,89 \%$.

\section{PEMBAHASAN}

Analisis data untuk pemecahan masalah yang telah dirumuskan pada penerapan SSR untuk peningkatan budaya baca secara diskriptif. Untuk pelaksanaan analisis data secara lebih konkrit, peneliti menganalisa data didapat dari teknik pengumpulan data penilaian jurnal membaca. Analisis hasil nilai jurnal membaca yang diisi peserta didik menggunakan kualifikasi yang telah ditetapkan oleh peneliti. Hasil wawancara terhadap petugas perpustakaan dan peserta didik dari siklus I dan siklus II terjadi peningkatan peserta didik meminjam buku. Berkaitan dengan buku bacaan diperpustakaan setuju memilih sesuai dengan keinginan kebutuhan. Hasil wawancara dengan peserta didik kurang setuju jika petugas perpustakaan yang menentukan buku yang akan dibaca, setuju menentukan sendiri judul buku sesuai dengan keinginannya. Peserta didik setuju jika guru pendamping di kelas saat wajib baca juga ikut membaca. Peserta didik juga setuju membuat ringkasan jurnal dengan bahasa sendiri.

Dilihat dari uraian diatas tidak kalah penting faktor eksternal selain buku perpustakaan juga 
sangat menentukan minat bembaca peserta didik. Hal tersebut diperkuat oleh pendapat Munaf (2002) yang menyatakan bahwa dalam menumbuhkan minat baca erat sekali hubungan dengan perpustakaan. Boediono (2004) juga menyatakan bahwa untuk membiasakan anak untuk membaca, sebenarnya adalah alternatif yang lebih murah dari membeli buku, yaitu anak bisa meminjam ataupun menumpang baca buku di perpustakaan. Dilihat dari peningkatan nilai hasil jurnal budaya baca dari rata-rata kelas siklus I dan siklus II meninggkat $27,89 \%$. Peningkatan budaya baca ini menunjukkan bahwa dengan penerapan Sustainabel Sailent Reading dapat meningkatkan budaya membaca peserta didik. Sustained Silent Reading merupakan satu proses periode membaca dalam hati tanpa ada proses lain yang mengganggu yang bertujuan untuk mendorong siswa membaca secara mandiri (Nurhidayati, 2012).

Budaya membaca perlu diprogramkan secara rutin, penerapan program wajib baca yang diterapkan disekolah dapat membiasakan peserta didik untuk meningkatkan budaya baca. Hal ini sesuai dengan hasil penelitian sebelumnya dengan diterapakan program wajib baca diharapkan dapat meningkatkan budaya baca. Menurut Nurhidayati (2012) peningkatan kualitas hasil minat membaca melalui penerapan program jam baca dapat dilihat dari peningkatan frekuensi membaca dan variasi bahan bacaan. menurut (Arisma, 2012) penerapan program jam baca mampu meningkatkan minat dan kemampuan membaca siswa. Walaupun semua tahu bahwa membaca mempunyai dampak positif, karena membaca merupakan modal dasar bagi peserta didik yang sedang menjalani proses belajar mengajar, mereka dapat mengembangkan daya imajinasinya dan yang lebih penting adalah dengan membaca peserta didik bisa mendapatkan ilmu yang bermacam-macam dan kelak akan bermanfaat bagi dirinya sendiri dan orang lain.

Namun menumbuhkan minat dan budaya membaca dalam kehidupan pelajar bukanlah hal yang mudah untuk dilakukan, pada kenyataannya minat baca pelajar sekarang ini kalah dengan media komunikasi yang sedang berkembang selama ini seperti handphone, televisi, dan warnet. Kebanyakan dari mereka lebih memilih untuk bermain game, lihat video. Hal ini banyak menyita waktu dan orang lebih memilih menikmati hiburan dibandingkan dengan membaca buku, sehingga jarang kita temukan pelajar yang gemar membaca. Sesuai pernyataan Kusmana (2009), berdasarkan hasil penelitian Programme for International Student Assessment, diketahui minat baca siswa rendah. Menurut Nurhidayati (2014) sustained silent reading merupakan satu proses periode membaca dalam hati tanpa ada proses lain yang mengganggu yang bertujuan untuk mendorong siswa membaca secara mandiri.

Ada tiga karakteristik dari sustained silent reading, yaitu: (1) self selection, siswa memiliki motivasi intrinsik yang lebih tinggi, teori motivasi intrinsik rasa ingin tahu siswa merupakan motivasi yang kuat untuk terus membaca, oleh karena itu dengan tingginya motivasi intrinsik siswa akan terus membaca sehingga pemahaman siswa menjadi meningkat; (2) role modeling, merupakan perilaku manusia dipelajari melalui mengamati dan meniru, untuk anak-anak perilaku dicontohkan oleh orang tua, guru, teman sebaya, apabila anak berada dalam lingkungan yang gemar membaca maka anak termotivasi untuk menjadi pembaca yang aktif pula, sehingga dalam sustained silent reading menunjukkan perilaku membaca merupakan hal yang penting untuk menumbuhkan perilaku positif dalam membaca; dan (3) nonaccountability, peserta didik tidak diharuskan membuat laporan atau ringkasan dari kegiatan sustained silent reading yang mereka lakukan (Nurhidayati, 2014). Tanpa adanya penugasan siswa akan menemukan kenikmatan dalam membaca sehingga mereka akan menyukai kegiatan membaca.

\section{SIMPULAN DAN SARAN}

Berdasarkan paparan dan analisis data penelitian dapat disimpulkan bahwa penerapan Sustainebel Salent Reading dapat meningkatkan budaya membaca peserta didik di SMP Negeri 05 Batu. Hal ini dapat dilihat dari hasil nilai jurnal membaca pada siklus I dengan nilai ratarata 62,86 , dan nilai jurnal rata-rata nilai siklus II 80,39 jadi dari pengamatan dua siklus terdapat kenaikan sebesar 27,89\%. Budaya membaca dapat meningkat dipengaruhi faktor internal yaitu minat seoarang untuk membaca dan faktor eksternal yaitu motivasi dan sarana dan prasarana yang ada.

Saran yang dapat diberikan untuk meningkatkan budaya membaca peserta didik 
dengan menerapkan SRR, juga perlu adanya motivasi dari pendidik dan kelengkapan sarana prasarana yang memadai. Untuk menambah kebenaran suatu cara penerapan SSR untuk meningkatkan budaya membaca maka perlu diterapkan di tempat yang lain.

\section{DAFTAR RUJUKAN}

Arikunto , S. 2006. Penelitian Tindakan Kelas. Jakarta: Bumi Aksara.

Arisma, O. A. 2012. Peningkatan Minat dan Kemampuan Membaca Melalui Penerapan Program Jam Baca Sekolah di Kelas VII SMP NEGERI 1 Puri. Skripsi tidak diterbitkan. Malang: Universitas Negeri Malang.

Boediono, W. 2004. Gemar Membaca, (Online), (http://www.mentaritimur.com/mentari/ dec04/gemar_membaca.htm), diakses 5 April 2016.
Kusmana, S. 2009. Minat Baca Siswa Rendah, (Online), (http://suherlicentre.blogspot. com/2009/01/minat-baca-siswarendah.html), diakses 4 Maret 2016.

Munaf, Y. 2002. Upaya Meningkatkan Minat Baca Siswa. Jurnal Pendidikan Bahasa Sastra dan Seni, 3(2): 241-250.

Nurhadi. 1987. Membaca Cepat dan Efektif. Bandung: Sinar Baru.

Nurhidayati. F. 2014. Peningkatan Keterampilan Membaca Pemahaman dengan Sustained Silent Reading di Kelas IV Sekolah Dasar Negeri Mendak Ponjong Gunung Kidul. Skripsi tidak diterbitkan. Yogyakarta. Universitas Negeri Yogyakarta.

Tampubolon. 1993. Mengembangkan Minat dan Kebiasaan Membaca Pada anak. Bandung: Angkasa. 